\title{
Sulindac induces differentiation of glioblastoma stem cells making them more sensitive to oxidative stress
}

\author{
S. K. ALLANI ${ }^{1, *}$, H. WEISSBACH ${ }^{1}$, M. A. LOPEZ-TOLEDANO ${ }^{1,2}$ \\ ${ }^{1}$ Center for Molecular Biology and Biotechnology, Charles E. Schmidt College of Science, Florida Atlantic University, Jupiter, Fl 33458, USA; \\ ${ }^{2}$ Current address: SCI, 2129 North Congress Ave, Riviera Beach, FL 33404, USA
}

*Correspondence: skesaraj@fau.edu

Received April 4, 2017/ Accepted August 5, 2017

\begin{abstract}
Glioblastoma tumors (GBM) are very heterogeneous, being comprised of several cell subtypes, including glioblastoma stem cells (GSC). These tumors have a high rate of recurrence after initial treatment and one of the most prevalent theories to explain this is the cancer stem cell theory, which proposes that glioblastomas arise from mutations that transform normal neural stem cells (NSC) into GSC, which are highly resistant to oxidative stress and anti-cancer therapies. Sulindac is a non-steroidal anti-inflammatory drug (NSAID) that has been shown to protect the normal cells against oxidative damage by initiating a preconditioning response, but selectively sensitizes several cancer cell lines to agents that affect mitochondrial respiration, resulting in enhanced killing of the cancer cells. These effects of sulindac are independent of its NSAID activity. There is little information on the effect of sulindac on normal and cancer stem cells. To study the effect of sulindac on both normal and cancer stem cells, we have isolated normal neural stem cells (NSC) from mice hippocampi and glioblastoma stem cells (GSC) from a glioma cell line, U87.

As expected from previous studies, sulindac can protect normal astrocytes against oxidative stress. Sulindac induces differentiation of both NSC and GSC cells and sulindac upregulates neurogenesis in NSC. The differentiated NSC are also protected from oxidative stress damage, whereas the differentiation of GSC by sulindac increases the sensitivity of these cells to agents that cause oxidative stress. The $\mathrm{S}$ epimer of sulindac is more effective than the R epimer in inducing neuronal differentiation in both NSC and GSC. These results indicate that the ability of sulindac to induce GSC differentiation may have therapeutic value in preventing tumor recurrence.
\end{abstract}

Key words: glioblastoma, stem cells, sulindac, oxidative stress, differentiation

Neural stem cells (NSC) grow in the presence of growth factors such as EGF and/or bFGF and have the potential to differentiate into neurons, astrocytes, and oligodendrocytes [1]. NSC have been isolated and grown in vitro from several regions of the embryonic and adult central nervous system, such as the subventricular zone (SVZ) [2, 3], cortex [4], spinal cord [5, 6] and midbrain [7]. However, only two regions show in vivo neurogenesis in adults: the SVZ [8-11] and the subgranular layer of the dentate gyrus in the hippocampus [12-16]. The regulation of self-renewal and neurogenesis in the central nervous system (CNS) is in part dependent on the redox status within the cells. Elevated levels of reactive oxygen species (ROS) increase neurosphere production and neurogenesis, as well as glial differentiation [17-22]. As cancer stem cells share several characteristics with normal stem cells, it is reasonable to think that their generation could be the consequence of specific changes in embryonic adult stem cells due to frequent cell divisions and mutation accumulation [23].

GBM are formed from a heterogeneous cell population. A subset of these cells retains the ability to repopulate the whole tumor when transplanted into mice [24]. This feature is the basis of the cancer stem cell theory, which states two important concepts: 1) tumors contain a number of cells that retain key stem cell properties and 2) tumorigenic cells arise from the transformation of tissue stem cells [25]. There is a clear relationship between the appearance of glioblastoma in NSC regions and its invasive and malignant features, supporting the theory that a specific transformation from a normal NSC to a glioblastoma stem cell (GSC) is involved in tumor initiation [26-28]. GSC are more resistant to traditional tumor treatments and they could be responsible for repopulating the heterogeneous GBM which would explain the high recurrence of tumors [25, 29-36]. Thus, GSC appear to be 
an excellent target to prevent tumor reappearance. Effective therapies to avoid glioblastoma recurrence could include a) inhibiting the NSC to GSC transformation, b) specific killing of the GSC or c) making them more sensitive to anti-cancer treatment [37-40].

Sulindac is a non-steroidal anti-inflammatory drug (NSAID) that is known to have anti-cancer activity towards different types of cancer when used alone or in combination with other treatments [41-47]. In our previous studies, it was demonstrated that sulindac sensitized cancer cells to agents that perturb mitochondrial respiration resulting in enhanced death, and this effect was independent of its NSAID activity $[48,49]$. In contrast, we found that sulindac could protect the normal heart and retinal pigmented epithelial (RPE) cells against oxidative damage by initiating an ischemic preconditioning response $[50,51]$. These studies demonstrated the differential role of sulindac in protecting normal cells against oxidative damage, while enhancing the killing of several cancer cells under similar conditions.

As noted above, cancer stem cells are more resistant to chemotherapy than the cancer cells that are derived after differentiation. Based on earlier studies on the effect of sulindac on normal and cancer cells exposed to oxidative stress $[48,49]$ our initial goal was to extend these studies to both normal and cancer stem cells to see what effect sulindac might have when these cells were exposed to oxidative stress. For these studies we examined the effect of sulindac on normal astrocytes, NSC, a glioblastoma cell line (U87), and GSC, after exposure to oxidizing agents or anticancer drugs that affect mitochondrial respiration. Our studies support the protective role of sulindac on normal cells (both mature astrocytes and NSC) and its ability to enhance the sensitivity of glioblastoma cells to oxidative stress. An important new finding is that sulindac induces differentiation of both NSC and GSC, and that the GSC derived cancer cells show enhanced sensitivity to oxidative stress.

\section{Materials and methods}

Cell cultures. NSC were obtained from the hippocampi of P0 BL6 mice and cultured in DMEM/F12 medium (Gibco, Thermo Fisher Scientific, Waltham, MA) containing B27 (Gibco, Thermo Fisher Scientific, Waltham, MA), epidermal growth factor, EGF (Invitrogen, Thermo Fisher Scientific, Waltham, MA) and basic fibroblast growth factor, bFGF (Peprotech, Rocky Hill, NJ).

Neural stem cell differentiation and astrocyte isolation. To induce cell differentiation, NSC were plated on poly-Llysine (PLL), obtained from Sigma, St. Louis, MO, where they spontaneously differentiate into neurons, astrocytes and oligodendrocytes as described elsewhere [52]. To obtain a pure culture of astrocytes, NSC were differentiated in DMEM $+10 \%$ FBS for seven days, trypsinized and re-plated in a new flask with the same medium. Under these circumstances, close to $100 \%$ of the cells become astrocytes (GFAP ${ }^{+}$cells).
DMEM and FBS were obtained from Gibco, Thermo Fisher Scientific, Waltham, MA.

Isolation of glioblastoma stem cells. U87 were obtained from ATCC (ATCC, Manassas, VA). GSC were obtained from the U87 cell line following the protocol previously published [53]. Briefly, the U87 cells were cultured in the same culture medium as NSC. After a few days, floating neurospheres were formed. The floating GSC neurospheres were isolated, mechanically disassociated and grown in suspension following the same protocol used for NSC. After two passages, a pure culture of floating GSC neurospheres was obtained.

Treatments. Sulindac was obtained from Sigma (Sigma, St.Louis, MO). The R and S epimers of sulindac were obtained from Regis Technologies Inc, Morton Grove, IL. Two types of sulindac treatments were used for both NSC and GSC.

In treatment 1 , we examined the effect of sulindac on floating, undifferentiated cells. In this treatment, the cells (both NSC and GSC) were treated as floating neurospheres for 24 hours with vehicle or sulindac and plated on PLL for another 24 hours in the presence of vehicle or drug, resulting in a total of $48 \mathrm{~h}$ of treatment.

The treatment 2 was used for GSC and NSC to observe the effect of sulindac on plated cells that were differentiated. After plating on poly-L-lysine (PLL), NSC start differentiating to neurons, astrocytes and oligodendrocytes. Cells were plated on PLL treated plates for five (GSC) or seven (NSC) days and treated for 48 hours with vehicle or sulindac. GSC were plated for 5 days, since these cells formed clusters and detached from the surface after 5 days of plating. Astrocytes (obtained as described in earlier section) were treated for 48 hours with vehicle or sulindac after 7 days post plating. U87 cells were treated for 48 hours, 24 hours after plating.

For GSC studies with dual drug combinations containing sulindac and anticancer drugs doxorubicin (DOX), dichloroacetate (DCA) and arsenic trioxide $\left(\mathrm{As}_{2} \mathrm{O}_{3}\right)$, the drugs were co- incubated with sulindac and the GSC for 48 hours before viability was measured. When tert-butyl hydroperoxide (TBHP) was used, it was added for two hours after the GSC were incubated for 48 hours with sulindac, as described previously [48]. The anti-cancer drugs were obtained from Sigma. (Sigma, St. Louis, MO). Figure 1 summarizes the treatments described above that were used to differentiate both NSC and GSC.

Imaging and immunocytochemistry. Phase contrast pictures were obtained using an AmScope $10 \mathrm{MP}$ camera attached to a Nikon TMS inverted microscope. Indirect immunocytochemistry (ICC) was performed as described previously [52, 54, 55]. Briefly, NSC were mechanically disaggregated and plated on PLL. For ICC, the following markers were used: monoclonal anti-nestin (clone Rat 401; 1:200, obtained from Developmental Studies Hybridoma Bank. University of Iowa, Iowa City, IA) for NSC staining and polyclonal anti- $\beta$-tubulin isotype III (1:2000; Covance, BioLegend, San Diego, CA 92121) for neuronal identifica- 
tion. Epifluorescence microscopes (Leica and Nikon) were used for pictures, counting and visualization of the immunocytochemistry. The total number of neurons was quantified by counting a minimum of 15 fields per treatment in triplicates or quadruplicates. The number of positive neurons was corrected for total cells in the same area, quantified with nuclear staining with Hoechst (Sigma-Aldrich, St. Louis, MO 63103), and normalized to non-treated cultures.

Western blot. Protein extraction for western blot and enzyme activity analysis was performed as described elsewhere [55]. We also used nestin, $\beta$-tubulin III and DCX (a marker for neuronal progenitor cells) and actin (Cell signaling Technologies, Danvers, MA) as a loading control for the detection of the different cell types by western blot.

Cell viability assay. NSC, GSC, astrocytes and U87 cells were plated at 10,000 cells per well in a PLL coated 96-well plate and the cell viability was measured as previously published [49]. Briefly, the cells were grown at $37^{\circ} \mathrm{C}$ in a $5 \% \mathrm{CO}_{2}$ incubator for a specified time, the medium discarded under aseptic conditions and replaced with fresh culture medium containing the indicated drug combinations for specified times described in the Results section. The culture medium was discarded and the cells were washed with PBS. Cell viability was determined by using the CellTiter 96 Aqueous One Cell Proliferation Assay (Promega, Madison, WI) according to the manufacturer's instructions. Cell viability was quantified by measuring the absorbance at $490 \mathrm{~nm}$ using a colorimetric microtiter plate reader (SpectraMax Plus; Molecular Devices). Background absorbance was subtracted from each sample. The graphs represent the percentage of cell survival compared to the control without TBHP treatment.

Statistical analysis. Analysis of variance (ANOVA) and multicomparison post hoc test (Bonferroni), Student's t-test and additional statistics were performed using the Prism4 program from GraphPad Software Inc. The graphs are represented as $\mathrm{SE} \pm$ mean. ${ }^{*} \mathrm{p}<0.05 ;{ }^{* *} \mathrm{p}<0.01 ;{ }^{\star * *} \mathrm{p}<0.001$.

\section{Results}

Isolation of NSC and GSC. As previously reported, NSC can grow almost indefinitely in culture in floating clusters of dividing cells called neurospheres (Figure 1, Figure 2A) $[1,7,56,57]$. NSC stop proliferating and start differentiating after attaching to an adherent substrate (PLL). Under these circumstances, NSC differentiate into neurons, astrocytes and hardly detectable levels of oligodendrocytes, plus a relatively small percentage of glial and neuronal progenitor cells, as previously published (Figure 2B) [57].We isolated pure astrocytes from NSC by maintaining the NSC culture in $10 \%$ FBS for several passages, as described in methods.

To isolate GSC, we used the U87 glioblastoma cancer cell line as described previously [53]. U87 cells (Figure 2C) when cultured in the presence of EGF and bFGF, yield GSC that grow as floating clusters of cells, similarly to NSC neurospheres (Figure 2D).

Sulindac induces differentiation of NSC and GSC. Under the various growth conditions summarized in Figure 1 , it is possible to compare the effect of sulindac on (i) normal cells (astrocytes and NSC) vs cancer cells (U87 and GSC) and (ii) stem cells before and after differentiation.

Figure 3 shows the increase in neuronal differentiation obtained after treating NSC with sulindac in both treatments 1 and 2. Figure 3A shows that NSC 24 hours post plating show a relatively low number of neurons ( $\beta$-tubulin III $^{+}$cells, red) without any drug. However, the number of neurons increased significantly after sulindac treatment (Figure 3B). Similar differences were found after five days post plating as seen with control NSC in Figure 3C compared to cells treated

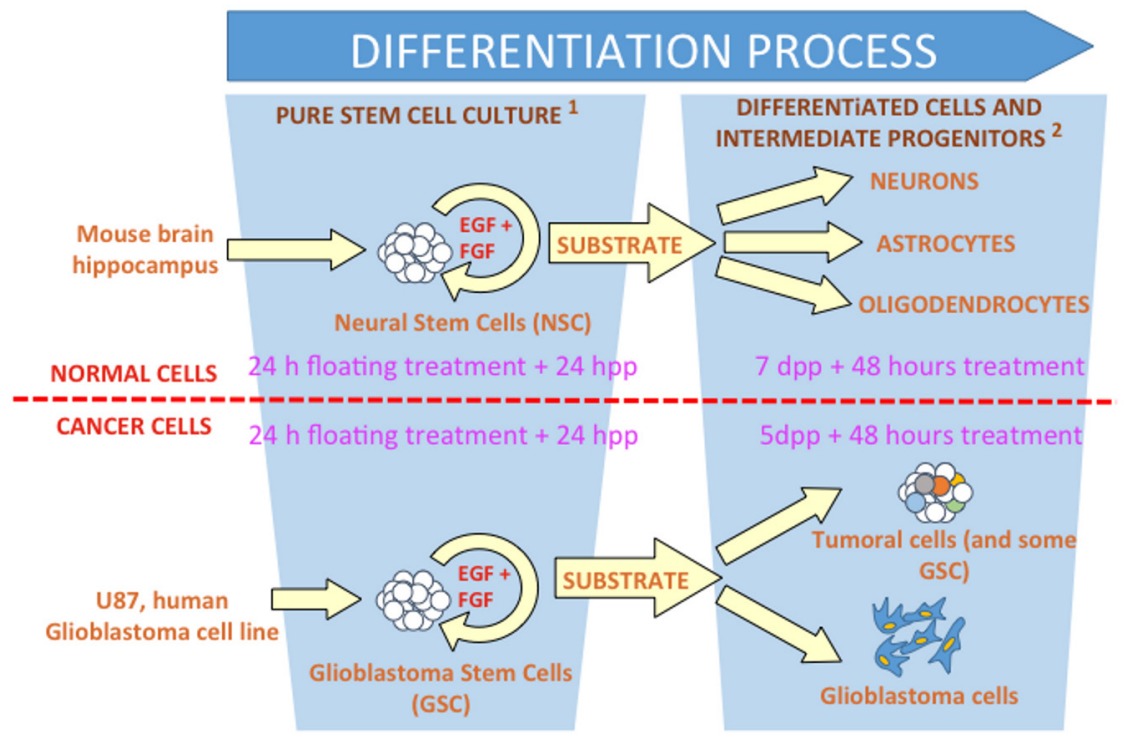

Figure 1. Treatments used to differentiate both normal neural and glioblastoma stem cells. ${ }^{1}$ UNDIFFERENTIATED CELLS: Floating NSC contain mostly nestin ${ }^{+}$undifferentiated cells. In order to see sulindac effect on undifferentiated stem cells, floating neurospheres (for both NSC and GSC) were treated for 24 hours with sulindac. Cells were then plated on PLL and quantified 24 hours post-plating (hpp).

${ }^{2}$ DIFFERENTIATED CELLS: 7 days post-plating (dpp), NSC progeny differentiates to mature neurons and glial cells with some glial and neuronal progenitors and almost no undifferentiated stem cells are present in the culture. NSC progeny was then treated for 48 hours with sulindac. Similarly, GSC were plated for 5 days before being treated with sulindac for $\mathbf{4 8}$ hours, to have a comparison normal vs. cancer cells. 

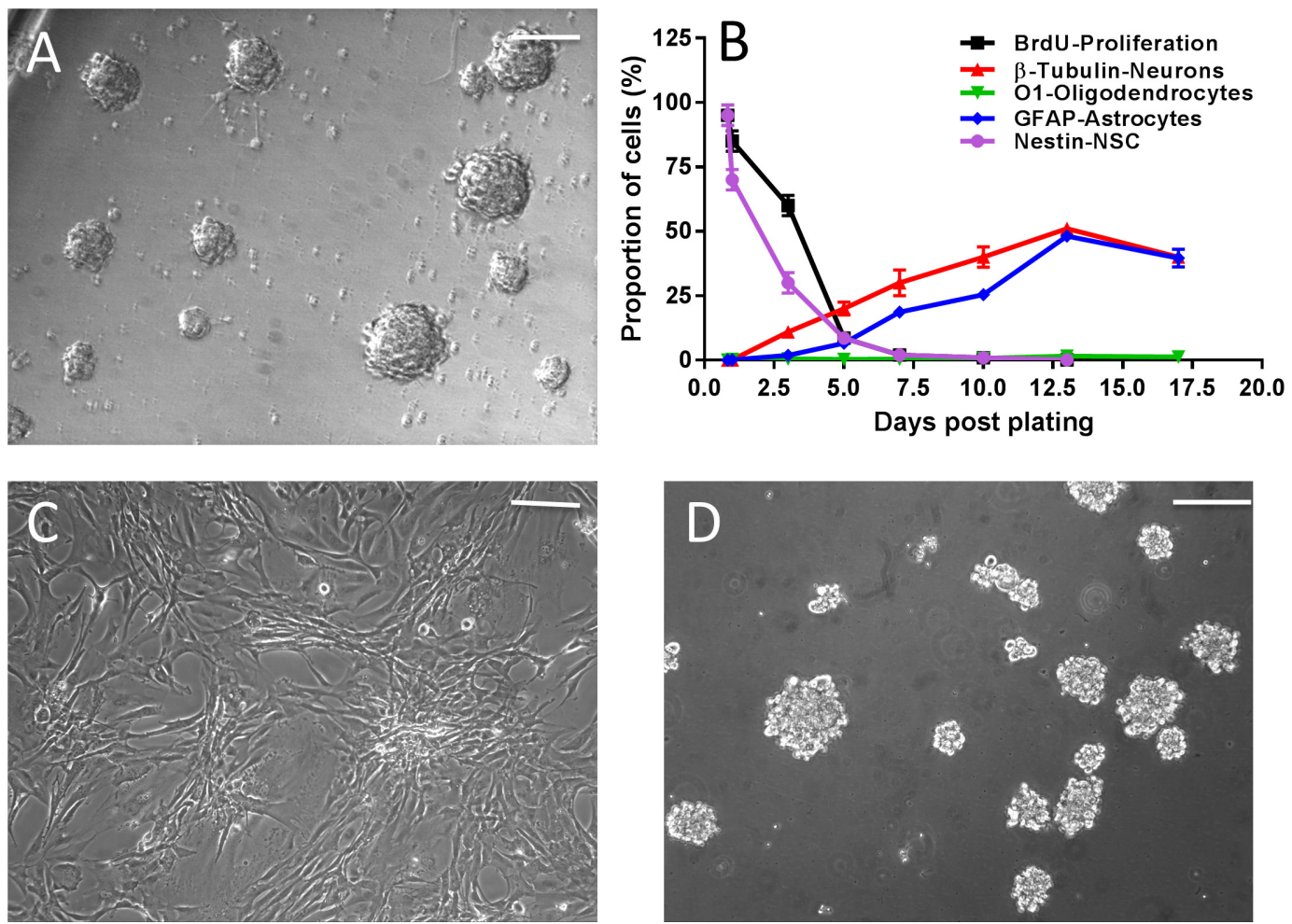

Figure 2. Cell culture of neural stem cells and isolation of glioblastoma stem cells. (A) Neural stem cells (NSC) grown in culture in the presence of EGF and bFGF as undifferentiated floating clusters of cells called neurospheres, (B) Time course spontaneous differentiation of NSC toward neurons, astrocytes and oligodendrocytes after plating them on poly-L-lysine. Adapted from [57], (C) U87 glioblastoma cell line, (D) Floating glioblastoma stem cells (GSC) derived from U87 cells growing as neurospheres in the presence of EGF and bFGF.
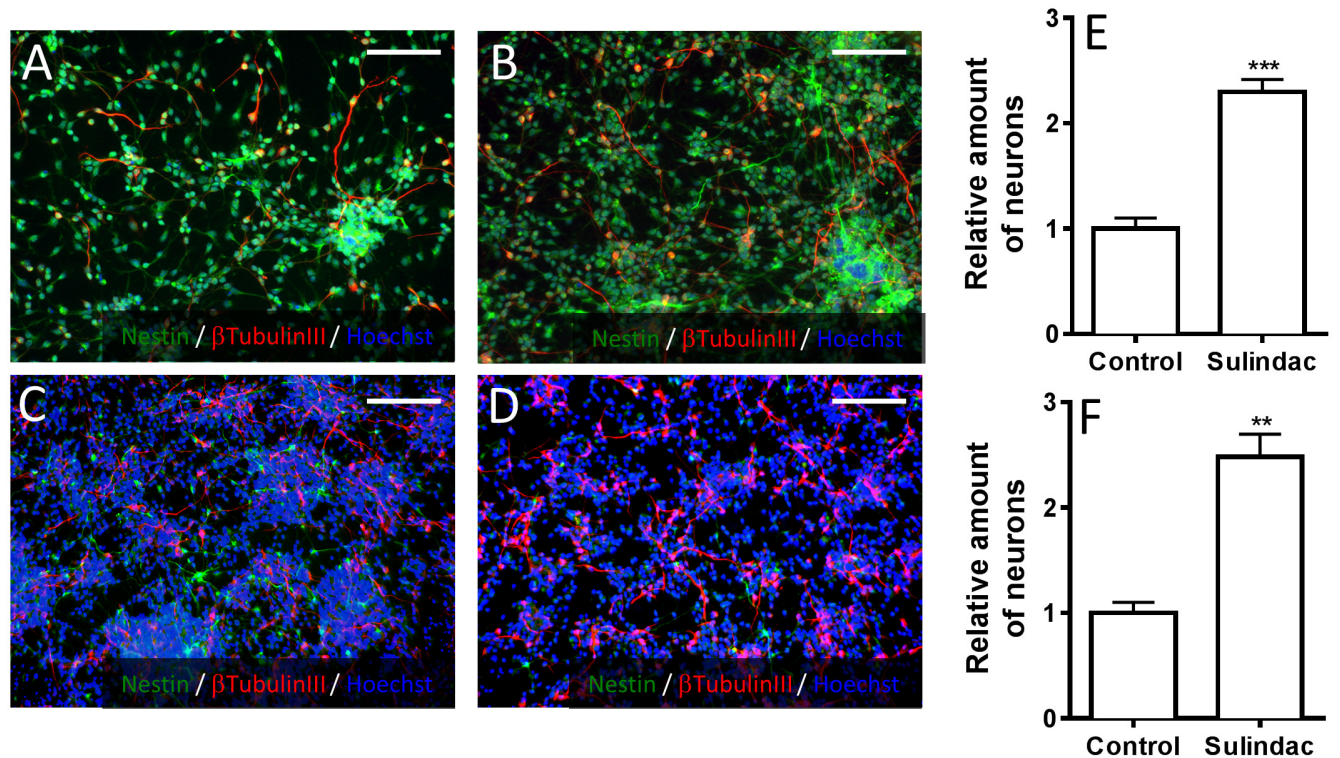

Figure 3. Sulindac induces neuronal differentiation of NSC. Photomicrographs with the neuronal-specific antibody $\beta$-tubulin III (red) and NSCspecific antibody nestin (green) performed at different time points, counterstained with the nuclear stain Hoechst (blue). (A) NSC treated with vehicle for $24 \mathrm{~h}$ and then plated on PLL for $24 \mathrm{~h}$, (B) NSC treated with sulindac for $24 \mathrm{~h}$ and then plated on PLL for $24 \mathrm{~h}$, (C) NSC plated on PLL for 7 days and treated with vehicle for $48 \mathrm{~h}$, (D) NSC plated on PLL for 7 days and treated with sulindac for $48 \mathrm{~h}$, (E) Comparison of percentage of neurons in NSC control and sulindac treated NSC after $24 \mathrm{~h}$ of treatment, (F) Comparison of percentage of neurons in control and sulindac treated NSC 7 days after plating and treatment with vehicle/sulindac for $48 \mathrm{~h}$. Sulindac concentration used: $500 \mu \mathrm{M}$. 
with sulindac (Figure 3D). The bar graphs in Figures 3E and Figure $3 \mathrm{~F}$ show the percentage of neurons, untreated vs treated after 24 hours and 7 days post plating.

Similar to NSC, floating GSC were mechanically disassociated and forced to attach to PLL. After plating, a high percentage of GSC remained growing as attached clusters both at 24 hours and 5 days (Figures $4 \mathrm{~A}, \mathrm{C}$ ). However, sulindac addition to cells both 24 hours post plating
(Figure 4B) and 5 days post plating (Figure 4D) shows a clear differentiation effect, with most cells attached to the plate forming a monolayer.

To test whether the morphological differentiation observed in Figures 4B and 4D after sulindac treatment corresponds to changes in the cellular phenotype, a series of experiments were performed to measure the levels of several cell-specific protein markers by western blot (Figure 4E).
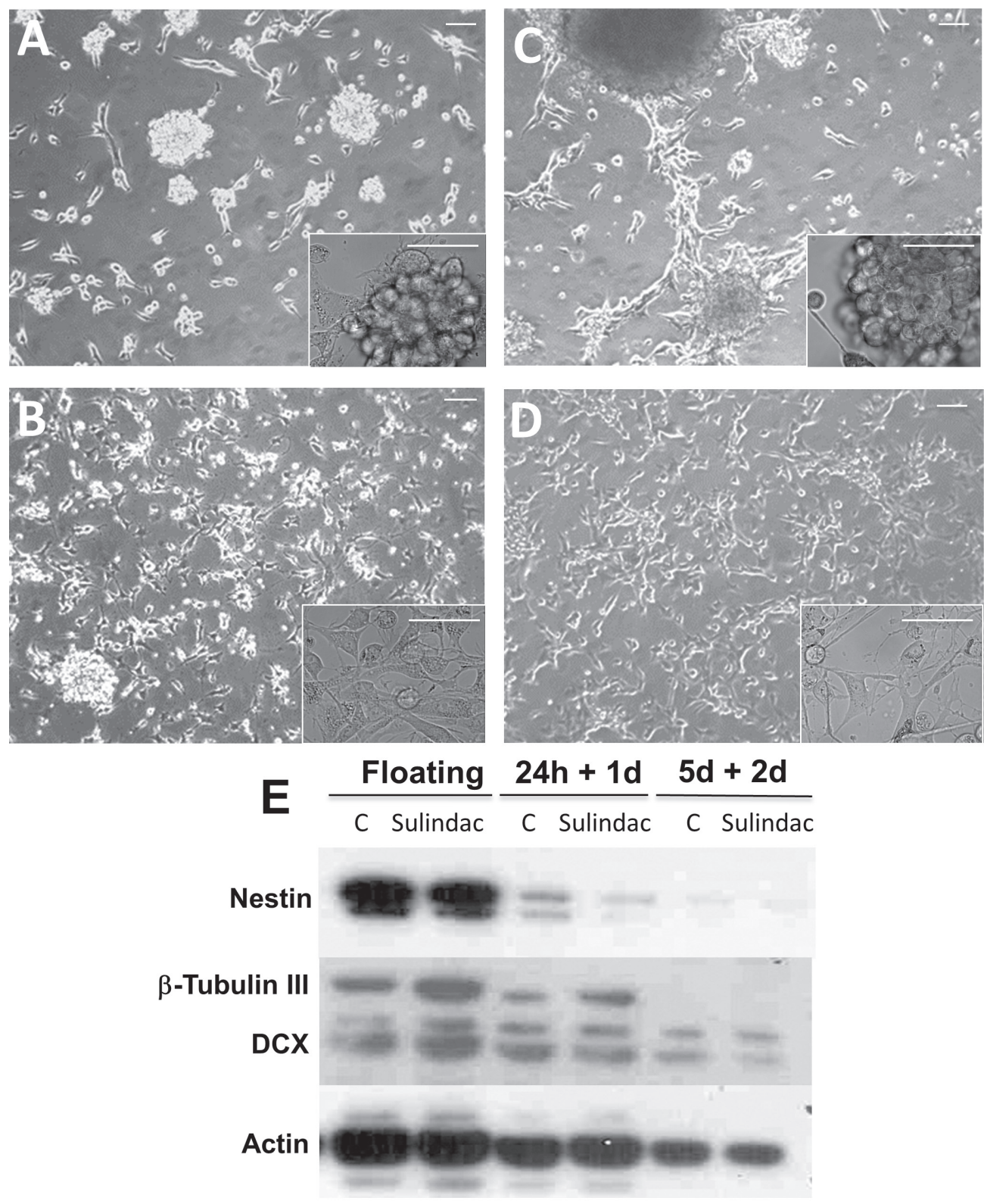

Figure 4. Sulindac induces morphological cell differentiation and increases neuronal markers in GSC. Low magnification phase contrast view of GSC with inserts showing higher magnification. Floating cells subjected to $24 \mathrm{~h}$ treatment followed by one day (24 hours) plating with (A) vehicle and (B) sulindac. GSC plated for 5 days followed by $48 \mathrm{~h}$ treatment with (C) vehicle and (D) sulindac. (E) Representative western blots: Floating: GSC treated in suspension for 24 hours, $24 \mathrm{~h}+1 \mathrm{~d}$ : GSC treated in suspension for 24 (Floating), followed by the same treatment for another 24 hours postplating and 5d + 2d: GSC treated for 2 days at the $5^{\text {th }}$ dpp. The samples were probed with antibodies against nestin, $\beta$-Tubulin III and doublecortin (DCX). Sulindac concentration used: $\mathbf{5 0 0} \mu \mathrm{M}$. Bar: $\mathbf{5 0}$ microns. 
Beta-tubulin III, a microtubule protein specific for neurons and doublecortin (DCX), a microtubule-associated protein expressed in neuronal precursor cells, were used to evaluate neuronal differentiation. As seen in Figure 4E, sulindac decreases the nestin levels and appears to induce neuronal differentiation of GSC with all treatments. Betatubulin III levels are low in control cells but when treated with sulindac, there is an increased expression in floating and $24 \mathrm{~h}$ post plating of differentiation while that of DCX did not change significantly. 5 days after plating, the expression of both Nestin and Beta-tubulin III markers decreased almost until undetectable levels were observed.

Sulindac differentially affects cell survival in NSC, GSC, astrocytes and glioblastoma cells exposed to oxidative stress. Our previous studies have shown a dual effect of sulindac since it can enhance the killing of cancer cells against oxidative stress while protecting normal cells under similar conditions $[48,49]$ In order to determine the sensi-
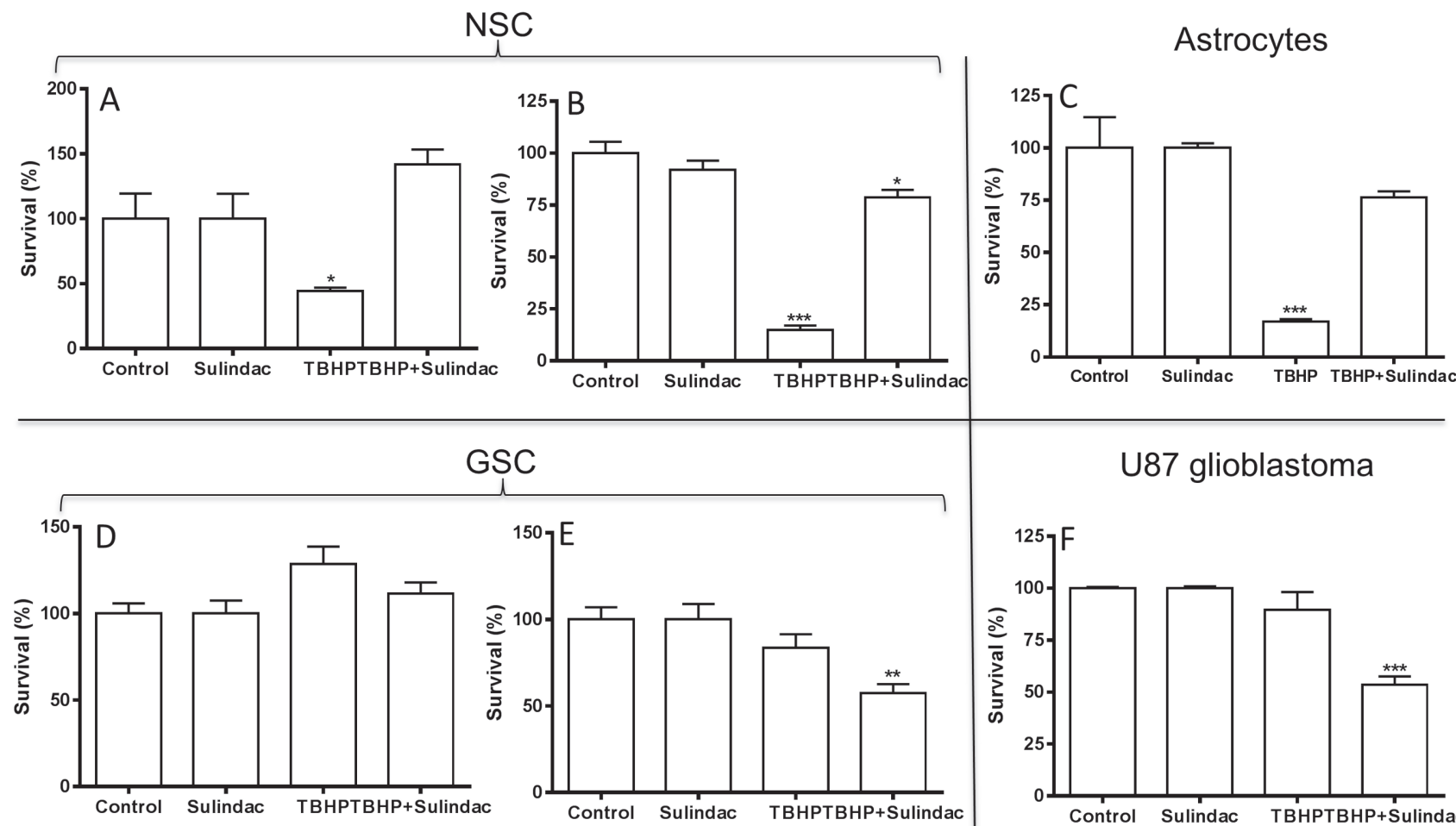

U87 glioblastoma

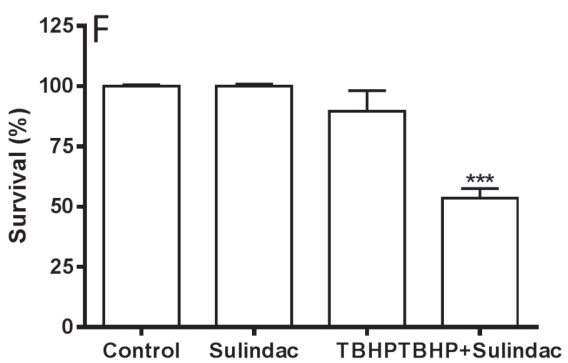

Figure 5. Sulindac differentially affects cell survival in NSC, astrocytes, U87 and GSC exposed to TBHP oxidative damage. Cell viability was determined using MTS assay (see methods). Effect of sulindac on (A) NSC after $24 \mathrm{~h}$ treatment, (B) NSC plated for seven days followed by 48 h treatment, (C) astrocytes plated for seven days followed by $48 \mathrm{~h}$ treatment, (D) GSC as floating neurospheres followed by treatment for 24 hours, (E) GSC plated for five days followed by $48 \mathrm{~h}$ treatment, (F) U87 plated for $24 \mathrm{~h}$ followed by $48 \mathrm{~h}$ treatment. Sulindac concentration was $500 \mu \mathrm{M}$ and the TBHP concentration was $200 \mu \mathrm{M}$.
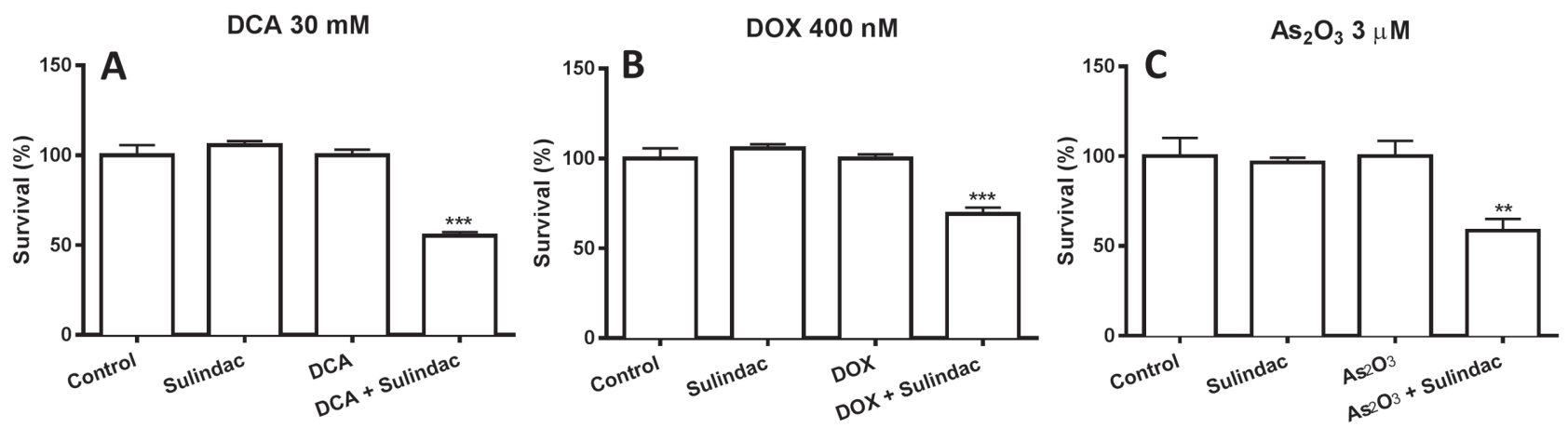

Figure 6. Sulindac sensitizes GSC to anticancer and oxidizing agents. Cell viability was determined in GSC plated for five days and treated for two days with vehicle or $500 \mu \mathrm{M}$ sulindac in the presence or absence of DCA, $30 \mathrm{mM}, \mathrm{DOX}, 400 \mathrm{nM}$ and $\mathrm{As}_{2} \mathrm{O}_{3} 3 \mu \mathrm{M}$. (A) sulindac and DCA, (B) sulindac and $\operatorname{DOX}(\mathrm{C})$ sulindac and $\mathrm{As}_{2} \mathrm{O}_{3}$. 
tivity of astrocytes, U87 glioblastoma cells, GSC and NSC to oxidative stress, tert-butyl hydroperoxide (TBHP) was used as the oxidizing agent, in the presence or absence of sulindac. The results are presented in Figure 5. After $24 \mathrm{~h}$ treatment, sulindac protects floating NSC from TBHP-induced death as seen in Figure 5A. After 7 days, sulindac also almost completely protects the NSC against TBHP-induced cell death (Figure 5B). A very similar protection with sulindac is also observed in cultured astrocytes treated with TBHP (Figure 5C). However, floating undifferentiated GSC were very resistant to oxidative stress, and show no enhanced killing when treated for 24 hours with sulindac (Figure 5D). In contrast, when GSC cells were plated for five days and then treated for two days with sulindac, the cells showed higher sensitivity to TBHP and sulindac treatment resulted in enhanced killing (Figure 5E), as compared with control NSC cells. A similar enhanced killing effect is observed in U87 glioblastoma cells treated with sulindac for 48 hours (Figure 5F).

These results suggest a protective effect of sulindac against oxidative stress in NSC and astrocytes with little or no effect on floating GSC. In contrast, sulindac increases sensitivity of U87 cells and differentiated GSC to oxidative stress, as shown previously with other cancer cell lines [48, 49]. In summary, these results support previous stem cell results, since GSC, like other stem cells, are very resistant to oxidative stress, but upon differentiation they behave like U87 cells.

Sulindac sensitizes differentiated GSC to agents that induce oxidative stress. In order to study the effect of sulindac in enhancing GSC killing after treatment with known anti-cancer drugs, the GSC cells were treated for 5 days, followed by a 2 day treatment with sulindac and/or the anticancer drugs, dichloroacetic acid (DCA), doxorubicin (DOX), or $\mathrm{As}_{2} \mathrm{O}_{3}$ (Figure $6 \mathrm{~A}-\mathrm{C}$ ). Dosage of these drugs was chosen based on earlier studies $([49,58-60])$. These anticancer drugs are known to cause oxidative stress in the cancer cells. As shown in Figure 6, under the conditions used, sulindac alone or the anticancer drugs by themselves showed little killing. However, there is enhanced killing of the differentiated GSC when sulindac is used in combination with any of the three different anticancer agents.

Sulindac-induced differentiation is independent of its NSAID activity. In order to see if the mechanism involved in the sulindac-induced cell differentiation of GSC is due to NSAID activity, ibuprofen, another NSAID was tested as well as sulindac sulphone, a sulindac metabolite that has no NSAID activity. Also, sulindac has a chiral sulfur center and it is an equal mixture of the $\mathrm{R}$ and $\mathrm{S}$ epimers and the individual epimers were also tested [61]. The results are shown in Figure 7. Compared to the control cells (Figure 7A), sulindac (an equal mixture of the $\mathrm{R}$ and $\mathrm{S}$ epimers) shows significant differentiation (Figure 7B). Sulindac sulfone also shows weak differentiation activity (Figure 7C), whereas ibuprofen has no activity (Figure 7D). The sulindac R-epimer is also inactive (Figure 7E), but the sulindac $\mathrm{S}$ epimer is the most potent differentiation agent (Figure 7F). It should be noted that sulindac sulfone was used at a much lower concentration because of its toxicity. These results indicate that the
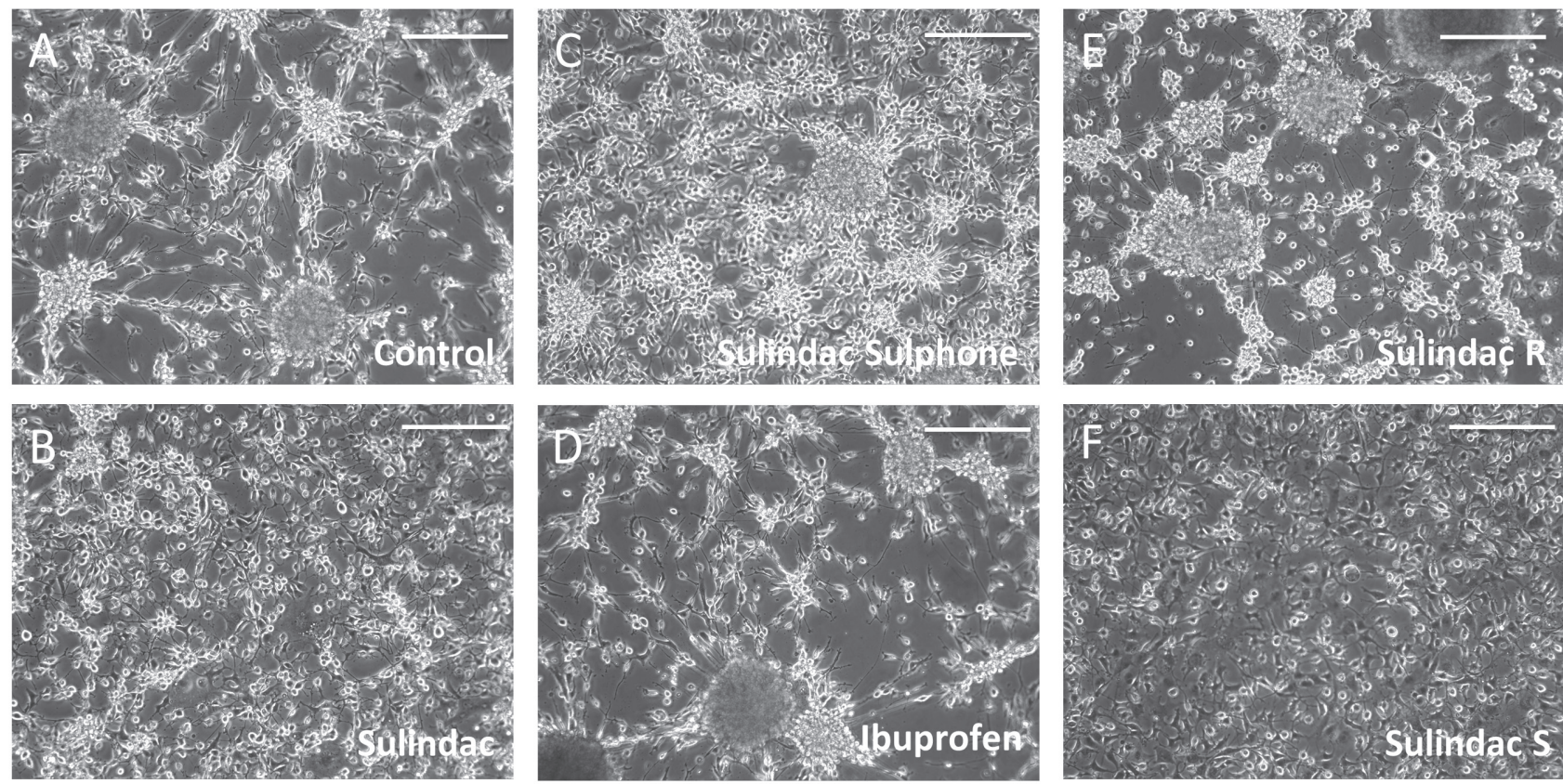

Figure 7. Sulindac-induced differentiation of GSC is independent of its NSAID activity and specific for its S epimer. Following 5-day post plating, GSC were treated for $48 \mathrm{~h}$ with (A) vehicle, (B) $500 \mu \mathrm{M}$ sulindac, (C) $25 \mu \mathrm{M}$ of sulindac suphone, (D) $400 \mu \mathrm{M}$ of ibuprofen, (E) $250 \mu \mathrm{M}$ of the R epimer of sulindac or (F) $250 \mu \mathrm{M}$ of the $\mathrm{S}$ epimer of sulindac. 
sulindac differentiating effect is independent of its NSAID activity, and appears to be primarily due to the $S$ epimer of sulindac.

Our results confirm and extend our previous findings that sulindac protects normal cells against oxidative stress, but enhances the killing of cancer cells when exposed to oxidative stress. In addition, sulindac stimulates cell differentiation of both NSC and GSC and more importantly, makes GSC more sensitive to oxidative stress.

\section{Discussion}

A major challenge in cancer therapy is to develop drugs that kill tumor cells without being toxic to normal cells and avoid cancer relapse by eliminating all possible cancer and cancer stem cells. Cancer stem cells are very resistant to chemotheraputic agents and retain their ability to repopulate the whole heterogeneous tumor cell population [62].There have been several studies focusing on differentiating cancer stem cells (CSC) of different tissues into a more differentiated state. All-trans retinoic acid has been successfully used in patients suffering from acute promyelocytic leukaemia, with or without combination with other chemotherapy agents $[63,64]$. Phorbol myristate acetate $[65,66]$ and dimethylsulfoxide [67] also induced maturation of the leukemic cell lines. A more effective treatment based on stimulation of CSC differentiation therapy would use a dual drug combination including a differentiating agent (s) with an anticancer drug(s), in order to eradicate both the CSC and non-CSC. One reported example involves inhibition of TGF beta, which induces the differentiation of breast CSC, in combination with paclitaxel to eliminate the fast proliferating non-CSC forming in the tumor [68]. Prabhakaran et al. [69] have shown that cisplatin inhibits breast cancer cell survival and also induces differentiation of breast cancer stem cells. There are other treatments able to induce cell differentiation. It has been reported that some growth factors have differentiating effects on normal brain cells, like BDNG and NGF. However, these growth factors have possible tumorigenic effects [70-72]. Our previous results showed that sulindac, in combination with DCA enhances cancer cell killing in several types of cancer in vitro [49].

In the case of glioblastoma, the heterogeneity of the tumor and the role of the stem cell microenvironment (niche) in the cancer progression has been studied [73]. It has been shown that GSC possess elevated resistance to chemotherapy and have a high capacity to regenerate the tumor by differentiation into highly proliferative cells [74]. There have been several approaches for eliminating this kind of tumor by targeting GSC [75]. The present study provides evidence that sulindac induces differentiation of GSC, making them susceptible to anti-cancer treatments. Sulindac is unique in its differentiation ability in comparison to other agents, since it can sensitize glioblastoma cells to oxidative damage while protecting normal glial cells against oxidative damage. The present results show that sulindac induces cell differentiation of both NSC and GSC and transforms GSC to a more differentiated cell type. Following treatment with sulindac, there was a decrease in nestin immunopositivity in both NSC and GSC indicative of loss of stem-like characteristics. In case of NSC, sulindac significantly augmented the beta tubulin expression pushing NSC towards neuronal phenotype. Sulindac treatment increased beta tubulin expression in GSC at specific time points. However, it was more complicated in GSC since there was an overall decrease in beta tubulin after few days in culture. It has been reported that GSC isolated from established cultures show significant decrease in beta tubulin expression after many days in culture [76]. This is also in agreement with other studies that show loss of beta tubulin expression in GSC cells under differentiation conditions [77]. Our results, consistent with previous literature suggest that GSC tend to differentiate more towards their original parental cell lineage [76, 77].

We have shown that sulindac-induced differentiation made GSC more susceptible to TBHP or drugs used in anticancer therapy, like DOX, DCA or $\mathrm{As}_{2} \mathrm{O}_{3}$ that create oxidative stress in the cancer cells. To our knowledge, there is only one other report indicating that sulindac can differentiate stem cells. Singh et al. showed that sulindac induced differentiation markers such as CD14, CD15 and CD115 in a population of human AML cells [78]. There is a clinical relevance to understanding this effect of sulindac since there are recent reports that suggest that forcing GSC to differentiate into neurons or astrocytes is one of the effective methods to reduce tumor growth or recurrence [79]. This morphological differentiation and decreased cell proliferation seems to be related to higher sensitivity of these differentiated cells to oxidative stress.

The mechanism by which sulindac induces neuronal differentiation is not clear. However, several authors have previously described a variety of mechanisms involved in glioblastoma proliferation and malignancy [80]. Supporting the hypothesis of common mechanisms of self-renewal and differentiation in the context of the cancer stem cell theory [81], our results show similarities between NSC and GSC in regards to their differentiation response to sulindac $[82,83]$. The morphological changes observed, with no clusters of proliferating cells, suggest that both sulindac and specifically the $S$ epimer induce cell differentiation and the exit of the cells out of the cell cycle. That, by itself would be a positive step in stopping cancer progression. Although the R epimer of sulindac did not appear to induce morphological differentiation of GSC, the cells did have a phenotypic change since they also became more sensitive to anti-cancer drugs. The effect of the R epimer may be a way to identify metabolic changes related to oxidative stress that occur before definitive signs of differentiation are observed.

It is known that in NSC redox balance plays a very important role in their maintenance and proliferation, as well as in their neuronal and glial differentiation $[84,85]$. Antioxidants like edaravone promote proliferation of NSC [86] and 
COX-2 regulates the proliferation of cells that have glioma stem like properties [87]. There have been other reports of the effects of non-steroidal anti-inflammatory drugs (NSAIDS) on proliferation and differentiation of NSC [87], as well as on CSC [88]. Sulindac is a prodrug with NSAID properties, and previous studies have shown that MsrA can reduce the $S$ epimer of sulindac to sulindac sulfide, an active COX inhibitor, and MsrB, or an MsrB like activity present in liver can reduce the $\mathrm{R}$ epimer to the active NSAID [61]. However, as shown in Figure 7, ibuprofen, a known NSAID, was unable to induce the GSC differentiation. In addition, sulindac sulfone, the oxidized metabolite of sulindac, which has no NSAID activity, could partially induce cell differentiation. Finally, the two epimers of sulindac have different abilities to differentiate stem cells, although both are NSAID prodrugs. These results suggest that the major differentiating effect of sulindac is not due to its ability to inhibit the COX enzymes. Our earlier studies showed that sulindac functioned as an ischemic preconditioning agent (IPC) in protecting the heart and retinal pigmented epithelial cells against oxidative damage resulting from ischemia/reperfusion treatment and from chemical oxidation $[50,51]$. There is no evidence yet that a preconditioning response is involved in the sulindac induced differentiation of both NSC and GSC.

The sulindac-induced enhanced killing of cancer cells exposed to oxidative stress has been previously described [48, 49], but the mechanism by which sulindac sensitizes cancer cells to agents that affect mitochondrial function is also not fully understood. The previous studies indicated that this effect of sulindac may be related to a fundamental metabolic difference between how normal and cancer cells generate energy through respiration, as first described by Warburg [89]. Cancer cells appear to have a defect in their respiratory chain and obtain as much as $40 \%$ of their energy from glycolysis even in the presence of adequate oxygen, whereas glycolysis in normal cells accounts for less than 5\% of the energy requirement. Many studies have shown that cancer cells are more sensitive to glycolysis inhibitors than normal cells $[90,91]$ and other studies have provided evidence that compounds that affect the mitochondria are more toxic to cancer cells than normal cells [92]. Our previous work showed that sulindac enhances cancer killing when used in combination with agents that affect mitochondrial function [49]. What is clear is that reactive oxygen species (ROS) are involved in both the preconditioning protective response elicited by sulindac in normal cells and sulindac's ability to enhance the killing of cancer cells exposed to oxidative stress, indicating a major role of mitochondria in both effects $[50,51]$.

Although much of our previous work has been in vitro, there are two clinical studies that support our cell culture results on cancer killing. A previous limited proof of concept clinical study demonstrated that sulindac, in combination with hydrogen peroxide, can be used as a treatment for precancerous skin squamous cells (actinic keratosis) [93]. In a much larger clinical study on the recurrence of advanced colon polyps, it was shown that the combination of sulindac and difluormethylornithine (DFMO) reduced the recurrence of polyps and the appearance of adenocarcinoma in these patients by $>80 \%$ over a 3 year period $[47,94]$.

The use of sulindac as a differentiating agent for GSC in combination with chemotherapy has some advantages compared with other known compounds. Sulindac is inexpensive, it has low toxicity and has been used clinically as an NSAID for many years. There is also evidence that it can cross the blood brain barrier. [61]. In addition, sulindac enhances cancer cell killing in the presence of oxidative stress $[48,49]$ and exerts a protective effect on normal cells against oxidative damage [50,51].

\section{Conclusion}

Glioblastoma is one of the most aggressive types of cancer that appears to resist all types of treatment approaches. In the heterogenous population of glioblastoma tumor cells, the stem cells confer the most resistance to therapies. In the present studies we demonstrate that sulindac induces GSC to shift to a more differentiated cell type and in addition, sulindac enhances selective tumor cell killing in the presence of both oxidizing and anti-cancer agents. Further studies are needed to understand the mechanism of action of sulindac in differentiating and selective sensitizing of cancer cells.

Acknowledgements: The work was supported by funds from the Florida Atlantic University Foundation to HW and the College of Science Seed Grant to MLT. We thank Ms. Xiaoping Wu for her assistance in carrying out some of the Western blot analyses.

\section{References}

[1] BAZAN E, ALONSO FJ, REDONDO C, LOPEZ-TOLEDANO MA, ALFARO JM et al. In vitro and in vivo characterization of neural stem cells. Histol Histopathol 2004; 19: 1261-1275. https://doi.org/10.14670/HH-19.1261

[2] REYNOLDS BA, WEISS S. Generation of neurons and astrocytes from isolated cells of the adult mammalian central nervous system. Science 1992; 255: 1707-1710.

[3] GRITTI A, FROLICHSTHAL-SCHOELLER P, GALLI R, PARATI EA, COVA L et al. Epidermal and fibroblast growth factors behave as mitogenic regulators for a single multipotent stem cell-like population from the subventricular region of the adult mouse forebrain. J Neurosci 1999; 19: 3287-3297.

[4] DAVIS AA, TEMPLE S. A self-renewing multipotential stem cell in embryonic rat cerebral cortex. Nature 1994; 372: 263 266. https://doi.org/10.1038/372263a0

[5] RAY J, GAGE FH. Spinal cord neuroblasts proliferate in response to basic fibroblast growth factor. J Neurosci 1994; 14: 3548-3564.

[6] WEISS S, DUNNE C, HEWSON J, WOHL C, WHEATLEY $\mathrm{M}$ et al. Multipotent CNS stem cells are present in the adult mammalian spinal cord and ventricular neuroaxis. J Neurosci 1996; 16: 7599-7609. 
[7] BAZAN E, LOPEZ-TOLEDANO M, REDONDO C, ALCAZAR A, MENA $M$ et al. Characterization of rat neural stem cells from embryonic striatum and mesencephalon during in vitro differentiation. pp. 133-147. In: B. Castellano, B. Gonzalez, M. Nieto-Sampedro (Eds.), Understanding Glial Cells. Kluwer Academic Publishers, 1998, p. 434. ISBN 9781461376286.

[8] LUSKIN MB. Restricted proliferation and migration of postnatally generated neurons derived from the forebrain subventricular zone. Neuron 1993; 11: 173-189.

[9] GOLDMAN JE. Lineage, migration, and fate determination of postnatal subventricular zone cells in the mammalian CNS. J Neurooncol 1995; 24: 61-64.

[10] LOIS C, ALVAREZ-BUYLLA A. Proliferating subventricular zone cells in the adult mammalian forebrain can differentiate into neurons and glia. Proc Natl Acad Sci U S A 1993; 90: 2074-2077.

[11] LOIS C, GARCIA-VERDUGO JM, ALVAREZ-BUYLLA A. Chain migration of neuronal precursors. Science 1996; 271 : 978-981.

[12] ALTMAN J, DAS GD. Post-natal origin of microneurones in the rat brain. Nature 1965; 207: 953-956.

[13] BAYER SA, YACKEL JW, PURI PS. Neurons in the rat dentate gyrus granular layer substantially increase during juvenile and adult life. Science 1982; 216: 890-892.

[14] KAPLAN MS, BELL DH. Mitotic neuroblasts in the 9-dayold and 11-month-old rodent hippocampus. J Neurosci 1984; 4: 1429-1441.

[15] STANFIELD BB, TRICE JE. Evidence that granule cells generated in the dentate gyrus of adult rats extend axonal projections. Exp Brain Res 1988; 72: 399-406.

[16] KUHN HG, DICKINSON-ANSON H, GAGE FH. Neurogenesis in the dentate gyrus of the adult rat: age-related decrease of neuronal progenitor proliferation. J Neurosci 1996; 16: 2027-2033.

[17] LE BELLE JE, OROZCO NM, PAUCAR AA, SAXE JP, MOTTAHEDEH J et al. Proliferative neural stem cells have high endogenous ROS levels that regulate self-renewal and neurogenesis in a PI3K/Akt-dependant manner. Cell Stem Cell 2011; 8: 59-71. https://doi.org/10.1016/j.stem.2010.11.028

[18] NOBLE M, PROSCHEL C, MAYER-PROSCHEL M. Oxidative-reductionist approaches to stem and progenitor cell function. Cell Stem Cell 2011; 8: 1-2. https://doi. org/10.1016/j.stem.2010.12.005

[19] LIMOLI CL, ROLA R, GIEDZINSKI E, MANTHA S, HUANG TT et al. Cell-density-dependent regulation of neural precursor cell function. Proc Natl Acad Sci U S A 2004; 101: 16052-16057. https://doi.org/10.1073/pnas.0407065101

[20] FORNAZARI M, NASCIMENTO IC, NERY AA, DA SILVA CC, KOWALTOWSKI AJ et al. Neuronal differentiation involves a shift from glucose oxidation to fermentation. J Bioenerg Biomembr 2011; 43: 531-539. https://doi.org/10.1007/ s10863-011-9374-3

[21] PANOPOULOS AD, YANES O, RUIZ S, KIDA YS, DIEP D et al. The metabolome of induced pluripotent stem cells reveals metabolic changes occurring in somatic cell reprogramming. Cell Res 2012; 22: 168-177. https://doi.org/10.1038/ cr.2011.177
[22] WALTON NM, SHIN R, TAJINDA K, HEUSNER CL, KOGAN JH et al. Adult neurogenesis transiently generates oxidative stress. PLoS One 2012; 7: e35264. https://doi. org/10.1371/journal.pone.0035264

[23] WANG Y, YANG J, ZHENG H, TOMASEK GJ, ZHANG $\mathrm{P}$ et al. Expression of mutant p53 proteins implicates a lineage relationship between neural stem cells and malignant astrocytic glioma in a murine model. Cancer Cell 2009; 15: 514-526. https://doi.org/10.1016/j.ccr.2009.04.001

[24] HEMMATI HD, NAKANO I, LAZAREFF JA, MASTERMAN-SMITH M, GESCHWIND DH et al. Cancerous stem cells can arise from pediatric brain tumors. Proc Natl Acad Sci U S A 2003; 100: 15178-15183. https://doi.org/10.1073/ pnas. 2036535100

[25] VESCOVI AL, GALLI R, REYNOLDS BA. Brain tumour stem cells. Nat Rev Cancer 2006; 6: 425-436.

[26] LIM DA, CHA S, MAYO MC, CHEN MH, KELES E et al. Relationship of glioblastoma multiforme to neural stem cell regions predicts invasive and multifocal tumor phenotype. Neuro Oncol 2007; 9: 424-429. https://doi. org/10.1215/15228517-2007-023

[27] HOLMBERG J, HE X, PEREDO I, ORREGO A, HESSELAGER $G$ et al. Activation of neural and pluripotent stem cell signatures correlates with increased malignancy in human glioma. PLoS One 2011; 6: e18454. https://doi.org/10.1371/ journal.pone.0018454

[28] ZAIDI HA, KOSZTOWSKI T, DIMECO F, QUINONESHINOJOSA A. Origins and clinical implications of the brain tumor stem cell hypothesis. J Neurooncol 2009; 93: 49-60. https://doi.org/10.1007/s11060-009-9856-x

[29] DIRKS PB. Brain tumour stem cells: the undercurrents of human brain cancer and their relationship to neural stem cells. Philos Trans R Soc Lond B Biol Sci 2008; 363: 139-152. https://doi.org/10.1098/rstb.2006.2017

[30] DEMETER K, ZADORI A, AGOSTON VA, MADARASZ E. Studies on the use of NE-4C embryonic neuroectodermal stem cells for targeting brain tumour. Neurosci Res 2005; 53: 331-342. https://doi.org/10.1016/j.neures.2005.08.003

[31] LIU W, SHEN G, SHI Z, SHEN F, ZHENG X et al. Brain tumour stem cells and neural stem cells: still explored by the same approach? J Int Med Res 2008; 36: 890-895. https://doi. org/10.1177/147323000803600504

[32] NELSON R. Brain-cancer stem cells may drive tumour formation. Lancet Neurol 2005; 4: 17-17.

[33] PICCIRILLO SG, VESCOVI AL. Brain tumour stem cells: possibilities of new therapeutic strategies. Expert Opin Biol Ther 2007; 7: 1129-1135. https://doi. org/10.1517/14712598.7.8.1129

[34] SANCHEZ-MARTIN M. Brain tumour stem cells: implications for cancer therapy and regenerative medicine. Curr Stem Cell Res Ther 2008; 3: 197-207.

[35] SUTTER R, YADIRGI G, MARINO S. Neural stem cells, tumour stem cells and brain tumours: dangerous relationships? Biochim Biophys Acta 2007; 1776: 125-137. https:// doi.org/10.1016/j.bbcan.2007.07.006 
[36] YU JJ, SUN X, YUAN X, LEE JW, SNYDER EY et al. Immunomodulatory neural stem cells for brain tumour therapy. Expert Opin Biol Ther 2006; 6: 1255-1262. https://doi. org/10.1517/14712598.6.12.1255

[37] CHENG L, BAO S, RICH JN. Potential therapeutic implications of cancer stem cells in glioblastoma. Biochem Pharmacol 2010; 80: 654-665. https://doi.org/10.1016/j. bcp.2010.04.035

[38] FINLAN LE, HUPP TR. Epidermal stem cells and cancer stem cells: insights into cancer and potential therapeutic strategies. Eur J Cancer 2006; 42: 1283-1292. https://doi. org/10.1016/j.ejca.2006.01.047

[39] ACHANTA P, SEDORA ROMAN NI, QUINONES-HINOJOSA A. Gliomagenesis and the use of neural stem cells in brain tumor treatment. Anticancer Agents Med Chem 2010; 10: 121-130.

[40] DIABIRA S, MORANDI X. Gliomagenesis and neural stem cells: Key role of hypoxia and concept of tumor "neo-niche". Med Hypotheses 2008; 70: 96-104. https://doi.org/10.1016/j. mehy.2007.04.024

[41] SCHEPER MA, NIKITAKIS NG, CHAISUPARAT R, MONTANER S, SAUK JJ. Sulindac induces apoptosis and inhibits tumor growth in vivo in head and neck squamous cell carcinoma. Neoplasia 2007; 9: 192-199.

[42] SHIFF SJ, QIAO L, TSAI LL, RIGAS B. Sulindac sulfide, an aspirin-like compound, inhibits proliferation, causes cell cycle quiescence, and induces apoptosis in HT-29 colon adenocarcinoma cells. J Clin Invest 1995; 96: 491-503.

[43] IZES JK, ZINMAN LN, LARSEN CR. Regression of large pelvic desmoid tumor by tamoxifen and Sulindac. Urology 1996; 47: 756-759.

[44] STURT NJ, PHILLIPS RK, CLARK SK. High-dose tamoxifen and Sulindac as first-line treatment for desmoid tumors. Cancer 2004; 101: 652. https://doi.org/10.1002/cncr.20416

[45] SUGANUMA M, OKABE S, KAI Y, SUEOKA N, SUEOKA E et al. Synergistic effects of (--)-epigallocatechin gallate with (--)-epicatechin, Sulindac, or tamoxifen on cancer-preventive activity in the human lung cancer cell line PC-9. Cancer Res 1999; 59: 44-47.

[46] YIP-SCHNEIDER MT, WU H, RALSTIN M, YIANNOUTSOS C, CROOKS PA et al. Suppression of pancreatic tumor growth by combination chemotherapy with Sulindac and LC-1 is associated with cyclin D1 inhibition in vivo. Mol Cancer Ther 2007; 6: 1736-1744. https://doi.org/10.1158/15357163.MCT-06-0794

[47] MEYSKENS JR FL, MCLAREN CE, PELOT D, FUJIKAWABROOKS S, CARPENTER PM et al. Difluoromethylornithine plus Sulindac for the prevention of sporadic colorectal adenomas: a randomized placebo-controlled, double-blind trial. Cancer Prev Res (Phila) 2008; 1: 32-38. https://doi. org/10.1158/1940-6207.CAPR-08-0042

[48] MARCHETTI M, RESNICK L, GAMLIEL E, KESARAJU S, WEISSBACH H et al. Sulindac enhances the killing of cancer cells exposed to oxidative stress. PLoS One 2009; 4: e5804. https://doi.org/10.1371/journal.pone.0005804
[49] AYYANATHAN K, KESARAJU S, DAWSON-SCULLY K, WEISSBACH H. Combination of Sulindac and Dichloroacetate Kills Cancer Cells via Oxidative Damage. PLoS One 2012; 7: e39949. https://doi.org/10.1371/journal.pone.0039949

[50] SUR A, KESARAJU S, PRENTICE H, AYYANATHAN K, BARONAS-LOWELL D et al. Pharmacological protection of retinal pigmented epithelial cells by Sulindac involves PPARalpha. Proc Natl Acad Sci U S A 2014; 111: 16754-16759. https://doi.org/10.1073/pnas.1419576111

[51] MOENCH I, PRENTICE H, RICKAWAY Z, WEISSBACH H. Sulindac confers high level ischemic protection to the heart through late preconditioning mechanisms. Proc Natl Acad Sci U S A 2009; 106: 19611-19616. https://doi.org/10.1073/ pnas.0911046106

[52] LOPEZ-TOLEDANO MA, SHELANSKI ML. Neurogenic effect of beta-amyloid peptide in the development of neural stem cells. J Neurosci 2004; 24: 5439-5444. https://doi. org/10.1523/JNEUROSCI.0974-04.2004

[53] YU SC, PING YF, YI L, ZHOU ZH, CHEN JH et al. Isolation and characterization of cancer stem cells from a human glioblastoma cell line U87. Cancer Lett 2008; 265: 124-134. https://doi.org/10.1016/j.canlet.2008.02.010

[54] LOPEZ-TOLEDANO MA and SHELANSKI ML. Increased Neurogenesis in Young Transgenic Mice Overexpressing Human APP(Sw, Ind). J Alzheimers Dis 2007; 12: 229-40.

[55] MODARRESI F, FAGHIHI MA, PATEL NS, SAHAGAN BG, WAHLESTEDT C et al. Knockdown of BACE1-AS Nonprotein-Coding Transcript Modulates Beta-Amyloid-Related Hippocampal Neurogenesis. Int J Alzheimers Dis 2011; 2011: 929042. https://doi.org/10.4061/2011/929042

[56] LOBO MV, ALONSO FJ, REDONDO C, LOPEZ-TOLEDANO MA, CASO E et al. Cellular characterization of epidermal growth factor-expanded free-floating neurospheres. J Histochem Cytochem 2003; 51: 89-103. https://doi. org/10.1177/002215540305100111

[57] MALAGELADA C, LOPEZ-TOLEDANO MA, WILLETT RT, JIN ZH, SHELANSKI ML et al. RTP801/REDD1 regulates the timing of cortical neurogenesis and neuron migration. J Neurosci 2011; 31: 3186-3196. https://doi. org/10.1523/JNEUROSCI.4011-10.2011

[58] JIN F, ZHAO L, ZHAO HY, GUO SG, FENG J et al. Comparison between cells and cancer stem-like cells isolated from glioblastoma and astrocytoma on expression of antiapoptotic and multidrug resistance-associated protein genes. Neuroscience 2008; 154: 541-550. https://doi.org/10.1016/j. neuroscience.2008.03.054

[59] GRUBER BM, BUBKO I, KRZYSZTON-RUSSJAN J, ANUSZEWSKA EL. Synergistic action of doxorubicin and Sulindac in human cervix carcinoma cells - studies on possible mechanisms. Med Sci Monit 2010; 16: BR45-51.

[60] DAS A, DURRANT D, MITCHELL C, MAYTON E, HOKE $\mathrm{NN}$ et al. Sildenafil increases chemotherapeutic efficacy of doxorubicin in prostate cancer and ameliorates cardiac dysfunction. Proc Natl Acad Sci U S A 2010; 107: 18202-18207. https://doi.org/10.1073/pnas.1006965107 
[61] BRUNELL D, SAGHER D, KESARAJU S, BROT N, WEISSBACH H. Studies on the metabolism and biological activity of the epimers of Sulindac. Drug Metab Dispos 2011; 39: 1014-1021. https://doi.org/10.1124/dmd.110.037663

[62] PATTABIRAMAN DR, WEINBERG RA. Tackling the cancer stem cells - what challenges do they pose? Nat Rev Drug Discov 2014; 13: 497-512. https://doi.org/10.1038/nrd4253

[63] ZHOU GB, ZHANG J, WANG ZY, CHEN SJ, CHEN Z. Treatment of acute promyelocytic leukaemia with all-trans retinoic acid and arsenic trioxide: a paradigm of synergistic molecular targeting therapy. Philos Trans R Soc Lond B Biol Sci 2007; 362: 959-71. https://doi.org/10.1098/rstb.2007.2026

[64] DE-MEDEIROS BC, STRAPASSON E, PASQUINI R, DEMEDEIROS CR. Effect of all-trans retinoic acid on newly diagnosed acute promyelocytic leukemia patients: results of a Brazilian center. Braz J Med Biol Res 1998; 31: 1537-1543.

[65] CAREY JO, POSEKANY KJ, DEVENTE JE, PETTIT GR, WAYS DK. Phorbol ester-stimulated phosphorylation of PU.1: association with leukemic cell growth inhibition. Blood 1996; 87: 4316-4324.

[66] WU H, SCHER BM, CHU CL, LEONARD M, OLMEDO R et al. Reduction in lactate accumulation correlates with differentiation-induced terminal cell division of leukemia cells. Differentiation 1991; 48: 51-58.

[67] ARCANGELI A, CARLA M, DEL BENE MR, BECCHETTI A, WANKE E et al. Polar/apolar compounds induce leukemia cell differentiation by modulating cell-surface potential. Proc Natl Acad Sci U S A 1993; 90: 5858-5862.

[68] BHOLA NE, BALKO JM, DUGGER TC, KUBA MG, SANCHEZ V et al. TGF-beta inhibition enhances chemotherapy action against triple-negative breast cancer. J Clin Invest 2013; 123: 1348-1358. https://doi.org/10.1172/JCI65416

[69] PRABHAKARAN P, HASSIOTOU F, BLANCAFORT P, FILGUEIRA L. Cisplatin induces differentiation of breast cancer cells. Front Oncol 2013; 3: 134. https://doi.org/10.3389/ fonc.2013.00134

[70] OKUGAWA Y, TANAKA K, INOUE Y, KAWAMURA M, KAWAMOTO A et al. Brain-derived neurotrophic factor/ tropomyosin-related kinase B pathway in gastric cancer. Br J Cancer 2013; 108: 121-130. https://doi.org/10.1038/ bjc.2012.499

[71] ZHU ZW, FRIESS H, WANG L, BOGARDUS T, KORC M et al. Nerve growth factor exerts differential effects on the growth of human pancreatic cancer cells. Clin Cancer Res 2001; 7: 105-112.

[72] PATANI N, JIANG WG, MOKBEL K. Brain-derived neurotrophic factor expression predicts adverse pathological \& clinical outcomes in human breast cancer. Cancer Cell Int 2011; 11: 23-23. https://doi.org/10.1186/1475-2867-11-23

[73] PERSANO L, RAMPAZZO E, BASSO G, VIOLA G. Glioblastoma cancer stem cells: role of the microenvironment and therapeutic targeting. Biochem Pharmacol 2013; 85: 612-622. https://doi.org/10.1016/j.bcp.2012.10.001

[74] CHEN J, LI Y, YU TS, MCKAY RM, BURNS DK et al. A restricted cell population propagates glioblastoma growth after chemotherapy. Nature 2012; 488: 522-526. https://doi. org/10.1038/nature11287
[75] CHO DY, LIN SZ, YANG WK, LEE HC, HSU DM et al. Targeting cancer stem cells for treatment of glioblastoma multiforme. Cell Transplant 2013; 22: 731-739. https://doi. org/10.3727/096368912X655136

[76] IACOPINO F, ANGELUCCI C, PIACENTINI R, BIAMONTE F, MANGIOLA A et al. Isolation of cancer stem cells from three human glioblastoma cell lines: characterization of two selected clones. PLoS One 2014; 9: e105166. https:// doi.org/10.1371/journal.pone.0105166

[77] WOLANCZYK M, HULAS-BIGOSZEWSKA K, WITUSIKPERKOWSKA M, PAPIERZ W, JASKOLSKI D et al. Imperfect oligodendrocytic and neuronal differentiation of glioblastoma cells. Folia Neuropathol 2010; 48: 27-34.

[78] SINGH R, CADEDDU RP, FROBEL J, WILK CM, BRUNS I et al. The non-steroidal anti-inflammatory drugs Sulindac sulfide and Diclofenac induce apoptosis and differentiation in human acute myeloid leukemia cells through an AP-1 dependent pathway. Apoptosis 2011; 16: 889-901. https://doi. org/10.1007/s10495-011-0624-y

[79] GUICHET PO, BIECHE I, TEIGELL M, SERGUERA C, ROTHHUT B et al. Cell death and neuronal differentiation of glioblastoma stem-like cells induced by neurogenic transcription factors. Glia 2013; 61: 225-239. https://doi. org/10.1002/glia.22429

[80] DUNN GP, RINNE ML, WYKOSKY J, GENOVESE G, QUAYLE SN et al. Emerging insights into the molecular and cellular basis of glioblastoma. Genes Dev 2012; 26: 756-784. https://doi.org/10.1101/gad.187922.112

[81] DIRKS PB. Brain tumor stem cells: the cancer stem cell hypothesis writ large. Mol Oncol 2010; 4: 420-430. https://doi. org/10.1016/j.molonc.2010.08.001

[82] LIGON KL, HUILLARD E, MEHTA S, KESARI S, LIU H et al. Olig2-regulated lineage-restricted pathway controls replication competence in neural stem cells and malignant glioma. Neuron 2007; 53: 503-517. https://doi.org/10.1016/j. neuron.2007.01.009

[83] ZHENG H, YING H, WIEDEMEYER R, YAN H, QUAYLE $\mathrm{SN}$ et al. PLAGL2. regulates Wnt signaling to impede differentiation in neural stem cells and gliomas. Cancer Cell 2010; 17: 497-509. https://doi.org/10.1016/j.ccr.2010.03.020

[84] YONEYAMA M, KAWADA K, GOTOH Y, SHIBA T, OGITA K. Endogenous reactive oxygen species are essential for proliferation of neural stem/progenitor cells. Neurochem Int 2010; 56: 740-746. https://doi.org/10.1016/j. neuint.2009.11.018

[85] SHYH-CHANG N, DALEY GQ, CANTLEY LC. Stem cell metabolism in tissue development and aging. Development 2013; 140: 2535-2547. https://doi.org/10.1242/dev.091777

[86] KIKUTA M, SHIBA T, YONEYAMA M, KAWADA K, YAMAGUCHI $\mathrm{T}$ et al. In vivo and in vitro treatment with edaravone promotes proliferation of neural progenitor cells generated following neuronal loss in the mouse dentate gyrus. J Pharmacol Sci 2013; 121: 74-83.

[87] SHARMA V, DIXIT D, GHOSH S, SEN E. COX-2 regulates the proliferation of glioma stem like cells. Neurochem Int 2011; 59: 567-571. https://doi.org/10.1016/j. neuint.2011.06.018 
[88] MOON CM, KWON JH, KIM JS, OH SH, JIN LEE K et al. Nonsteroidal anti-inflammatory drugs suppress cancer stem cells via inhibiting PTGS2 (cyclooxygenase 2) and NOTCH/ HES1, and activating PPARG in colorectal cancer. Int J Cancer 2014; 134: 519-529. https://doi.org/10.1002/ijc.28381

[89] WARBURG O. On the origin of cancer cells. Science 1956; 123: 309-14.

[90] AHMAD IM, AYKIN-BURNS N, SIM JE, WALSH SA, HIGASHIKUBO R et al. Mitochondrial O2* - and $\mathrm{H} 2 \mathrm{O} 2$ mediate glucose deprivation-induced stress in human cancer cells. J Biol Chem 2005; 280: 4254-63. https://doi.org/10.1074/jbc. M411662200

[91] AYKIN-BURNS N, AHMAD IM, ZHU Y, OBERLEY LW, SPITZ DR. Increased levels of superoxide and $\mathrm{H} 2 \mathrm{O} 2$ mediate the differential susceptibility of cancer cells versus normal cells to glucose deprivation. Biochem J 2009; 418: 29-37. https://doi.org/10.1042/BJ20081258
[92] RALPH SJ, LOW P, DONG L, LAWEN A, NEUZIL J. Mitocans: mitochondrial targeted anti-cancer drugs as improved therapies and related patent documents. Recent Pat Anticancer Drug Discov 2006; 1: 327-346.

[93] RESNICK L, RABINOVITZ H, BINNINGER D, MARCHETTI M, WEISSBACH H. Topical Sulindac combined with hydrogen peroxide in the treatment of actinic keratoses. J Drugs Dermatol 2009; 8: 29-32.

[94] LAUKAITIS CM and GERNER EW. DFMO: targeted risk reduction therapy for colorectal neoplasia. Best Pract Res Clin Gastroenterol 2011; 25: 495-506. https://doi.org/10.1016/j. bpg.2011.09.007 